\title{
ESENSI PROGRAM BIMBEL MANASIK HAJI UPAYA \\ PEMBERDAYAAN MASYARAKAT
}

\author{
Abdul Choliq \\ UIN Walisongo Semarang \\ Email : abdulcholiq@gmail.com
}

\begin{abstract}
Haij is the perfect worship of the pillars of Islam that became the goal of all Muslims in the world. So many hajj pilgrims who register to go to the Holy Land every year. Haij implementation annually put aside various problems. One of them is not the optimal of the bajj manasike given by Ministry of Religion and the long departure time of hajj, while the candidate is dominated by the elderly (elderly). The ministry has a great desire to form an independent hajj, so becomes an important issue to be observed. Writing scientific paper aims to provide a good view to the Ministry of Religious Affairs or the guidance of pilgrimage to provide bajj manasik not just a manasik in general, but really oriented to empowering prospective pilgrims to form an independent hajj. Some of things that must be done is first to use the right methods such as Affirmation and Repetition and PAIKEM, both utilizing long waiting times with useful activities.Such as training in making signs of haj pilgrimage (such as marking ribbons, masks, or slendang neck), training planting of live pharmacies, and making some goods to prepare for the departure of pilgrimage (eg small bags for storage of goods and others). Third is to grow independent congregations in a way more opportunities to meet with other congregations in order to grow optimism in prospective pilgrims.
\end{abstract}

Keywords: Hajj, guidance manasik, empowerment

\begin{abstract}
Abstrak
Haji merupakan ibadah penyempurna rukun Islam yang menjadi tujuan seluruh muslim di dunia. Sehingga setiap tahun banyak jama'ah haji yang mendaftarkan diri untuk berangkat ke Tanah Suci. Pelaksanaan Haji setiap tahunnya menyisihkan problematika bermacam-macam, salah satunya ialah belum optimalnya manasik haji yang diberikan oleh Kemenag dan waktu tunggu keberangkatan haji yang lama, sedangkan calon jamaah di dominasi oleh lansia (orang lanjut usia). Kementrian sendiri memiliki keinginan besar untuk membentuk haji mandiri, maka demikian itu menjadi permsalahan yang penting untuk di teliti. Penulisan karya tulis ilmiah ini bertujuan untuk
\end{abstract}


memberikan pandangan baik kepada Kemenag atau bimbel haji agar memberikan mansik haji tidak hanya sekedar manasik pada umumnya, tetapi betul-betul berorientasi pada pemberdayaan calon jamaah agar membentuk haji mandiri. Beberapa hal yang harus dilakukan ialah pertama menggunakan metode yang tepat seperti Affirmation and repetition dan PAIKEM, kedua memanfaatkan waktu tunggu yang begitu lama dengan kegiatan-kegiatan bermanfaat seperti bersama-sama dalam pembuatan tanda-tanda perbekalan haji, seperti pembuatan tanda pita, masker, atau slendang leher, melatih penanaman tanaman apotik hidup, dan pembuatan beberapa barang untuk memepersiapkan keberangkatan haji, misalnya tastas kecil untuk penyimpanan barang dan lainnya. Ketiga ialah dengan menumbuhkan jamaah mandiri dengan cara lebih banyak memberikan peluang temu dengan jamaah lain agar tumbuh optimisme dalam diri calon jamaah.

Keywords: Haji, bimbingan manasik, pemberdayaan

\section{LATAR BELAKANG}

Haji merupakan ibadah yang memiliki rukun berbeda dengan ibadah Islam yang lain, yaitu menjalankan ritual perjalanan yang tempat dan waktunya memiliki aturan tertentu. Aturan pelaksanaan haji ialah hanya dilaksanakan di Tanah Haram dan pada bulan Dzulhijjah. Pada waktu tersebut seluruh umat Islam dari seluruh penjuru dunia berbondongbondong pada tujuan yang sama, sehingga setiap umat dituntut mampu menyesuaikan dengan kondisi baik lingkungan sosial dan budaya yang ada.

Di tanah Haram ritual haji dilaksanakan dengan tujuan utama ialah untuk berdo'a di tempat-tempat yang mustajab seperti Ka'bah dan Mas'a, Arafah, Musdzalifah, dan Mina. ${ }^{1}$ Di tempat-tempat tersebut setiap ritual dilaksanakan secara bersama, sehingga kondisi di lokasi-lokasi tersebut tentu sangat luar biasa karena tidak hanya ratusan atau jutaan orang yang

${ }^{1}$ Murad Wilfred Hoffman, Jalan Meniju Mekkah, Terj: Abdul Hayyie al Kattani dkk, (Jakarta: Gema Isnasi Press, 2000), h, 32. 
berkumpul melainkan ratusan juta umat Islam melaksanakannya dan tidak ada pembeda cara pelaksanakan sebagaimana pemahaman empat mazhab. Umat Islam menjalankan wukuf, mabit, lempar jumrah, tawaf dan sa'I dengan cara dan di tempat yang sama sehingga dibutuhkan pemahaman yang sama. Haji pada dasarnya merupakan bentuk ibadah penyempurna rukun Islam, sehingga sebagian orang memaknai haji sebagai ibadah wajib bagi umat Islam yang memiliki kemampuan secara financial, fisik, dan aman dalam perjalanan. Allah mewajibkan umat Islam untuk menjalankan haji sebagaimana yang di nyatakan dalam Q.S. Al-Imron ayat 97:

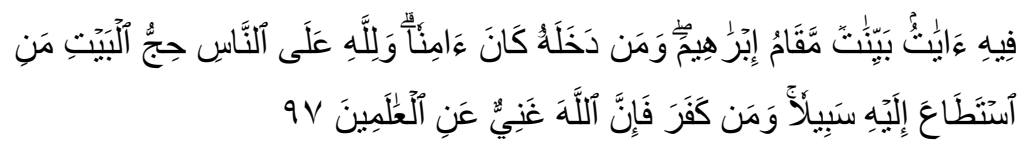

Padanya terdapat tanda-tanda yang nyata, (di antaranya) maqam Ibrabim; barangsiapa memasukinya (Baitullah itu) menjadi amanlah dia; mengerjakan haji adalah kewajiban manusia terbadap Allah, yaitu (bagi) orang yang sanggup mengadakan perjalanan ke Baitullah. Barangsiapa mengingkari (kewajiban haji), maka sesunggubnya Allab Maha Kaya (tidak memerlukan sesuatu) dari semesta alam.

Parameter "mampu" ialah mampu untuk melaksanakannya, sehingga diantara wajib haji selain beragama Islam, baligh, berakal ialah mampu dalam fisik, harta, dan mental. Pemahaman "mampu" menurut sebagain ulama memiliki perbedaan pendapat, namun beberapa interpretasi terhadap syarat mampu (istita'ah) sesuai al-Qur'an dapat dipahami sebagai "segala sesuatu yang menjadikannya bisa melakukan rukun haji dengan sempurna tanpa hambatan apapun tanpa hambatan maksudnya ialah perasaan aman dalam perjalanan, nafkah untuk keluarga yang ditinggalkan tercukupi dan bagi perempuan ada yang menjaga baik mahramnya atau bersama pesegala sesuatu yang menjadikannya bisa melakukan rukun haji dengan sempurna tanpa hambatan apapun tanpa hambatan maksudnya ialah perasaan aman dalam perjalanan, nafkah untuk keluarga yang ditinggalkan tercukupi dan bagi perempuan ada yang menjaga baik mahramnya atau bersama 
perempuan yang dipercayarempuan yang dipercaya". ${ }^{2}$ Mampu pada dasarnya berhubungan dengan kesehatan, keamanaan, dan biaya meski demikian kesiapan tentang ilmu agama yang berhubungan dengan pelaksanaan juga faktor penting yang harus dimiliki oleh calon jamaah haji untuk disebut mampu.

Kesempurnaan haji merupakan dambaan setiap umat Islam sedangkan hal tersebut bukanlah gampang untuk diwujudkan. Karena setiap jamaah disyaratkan mampu memahami setiap ketentuan ibadah baik yang di wajibkan, mubah, bahkan yang dilarang dalam haji. Namun kenyataan di lapangan menunjukkan umat Islam masih lemah tingkat pemahaman tentang beberapa ketentuan ibadah haji dan kekhwatiran yang berlebihan. Kekhawatiran tersebut dikarenakan perbedaan kondisi sosial dan budaya (seperti perbedaan bahasa, kebiasaan/ tradisi, banyaknya jamaah yang lain sehingga takut keluar dari regu jamaah, dan lainnya), ${ }^{3}$ maka perlunya pemahaman dan pemantapan yang baik sebelum keberangkatan. Sayangnya fakta di lapangan menyatakan bahwa manasik haji sebagai media utama pembekalan haji dan umroh hanya dilakukan beberapa kali dalam kurun waktu yang singkat dan terkadang masih belum semua materi tersampaikan. ${ }^{4}$ Kondisi ini hendaknya menjadi fokus yang harus diselesaikan, apalagi calon jamaah Indonesia. Permasalahan kebingungan Calhaj (Calon Jamaah Haji) Indoensia dikarenakan keraguan (parno) saat melakanakan ibadah berakar pada pemahaman yang seadanya.

\footnotetext{
${ }^{2}$ Widyarini, Penyelenggara Ibadah Haji bagi Lansia, Jurnal: Az Zarqa', Vol.8, No.2 Desember 2016.

3 Pikiran Rakyat, Jemaah Haji Harus Pabami Budaya Arab, diakses dalam http://www.pikiran-rakyat.com/info-haji/2013/09/24/252076/jemaah-haji-haruspahami-budaya-arab, pada Jum'at 10 Mei 2018, pukul 00.32 WIB.

${ }^{4}$ Republika.co.id, 'Bimbingan Manasik Haji Kurang Optimal, di posting pada 30 desember 2015 pukul 16.54 WIB.
} 
Indoensia sebagai negara mayoritas penduduk muslim memiliki jumlah calhaj yang tidak sedikit, berdasarkan catatan dari tahun 2001 sampai 2013, calon pendaftar jamaah haji Indonesia mencapai 4.998 .499 orang. ${ }^{5}$ Jika dikurangi dengan yang sudah berangkat, sampai saat ini jumlah jamaah haji Indonesia yang masih menunggu antrian keberangkatan sebanyak 2,2 juta orang. Sedangkan dari data website Kemenag RI, jumlah pendaftar ibadah haji di Indonesia, tiap bulannya mencapai 40.000 jamaah. ${ }^{6} \mathrm{Hal}$ ini membuat kementrian Agama memberikan batas dan aturan bagi calon jamaah yang akan berangkat haji setiap tahunnya. Diantaranya ialah adanya prioritas yang akan diberangkatkan yaitu para lansia (yang berusia 75 tahun ke atas). Pertimbangan prioritas tersebut dikarenakan kondisi jamaah dari segi kesehatan dan keselamatan.Prioritas tersebut mengakibatkan banyaknya kursi tunggu yang diduduki oleh calon jamaah, terlebih mereka yang berada pada usia diantara 45-50 tahun. Sedangkan dalam surat kabar online disebutkan bahwa Ketua Komisi Agama DPR, Ali Taher menyampaikan "masa tunggu calon jamaah haji di Indonesia sudah mencapai 41 tahun". Masa tunggu yang begitu lama mengakibatkan jamaah mengalami kejenuhan dan kebimbangan. Kejenuhan dan kebimbangan ini junstru akan mengancam kesehatan calon jamaah, karena secara psikis akan membuat jamaah setres.

Sebagaimana pemahaman "mampu" dan realitas di atas, menunjukkan ketimpangan sebab "mampu" utamanya ialah sehat jasmani dan rohani barulah biaya. Waktu tunggu yang begitu lama sebaikanya dimanfaatkan oleh jamaah dengan sebaik mungkin, disinilah bimbingan belajar manasik

\footnotetext{
${ }^{5}$ Reni Shiren Aulia, Jumlah Jemaah Haji Indonesia Yang Masuk Daftar Tunggu! http://www.alshaumroh.com/2017/02/jumlah-jemaah-haji-indonesia-yang-masukdaftar-tunggu.html, diakses pada Jum'at 10 Mei 2018 pukul 00. 54 WIB.
} 
haji menjadi salah satu solusi untuk memberikan sumbangsihnya tidak hanya dalam mengatasi pemahaman tentang ibadah haji dan umroh tetapi juga memanfaatkan waktu tunggu dengan hal yang berguna. Kondisi di atas merupakan problem yang perlu diselesaikan karena dapat membatalkan atau mengganggu mabrurnya bahkan sahnya haji. Oleh karena itu, perlunya intensifitas bimbingan yang dilakukan oleh lembaga atau petugas haji dan umroh.

Berdasarkan uraian di atas, penulis merasa tertarik untuk melakukan kajian secara mendalam dengan rumusan masalah "Bagaimanakah upaya yang dapat dilakukan oleh bimbingan belajar manasik Haji dalam memberdayakan umat?

\section{PEMBAHASAN}

\section{A. Program Bimbel Manasik Haji}

Secara esensisal bimbingan belajar manasik haji merupakan gabungan dari bimbingan, manasik, dan haji. Bimbingan dalam bahasa inggris berarti "guidance" ialah bantuan, arahan, pedoman, dan petunjuk. Sejak awal kemunculannya bimbingan bertujuan mengarahkan individu melalui usahanya sendiri untuk menentukan dan mengembangkan kemampuannya agar memperoleh kemanfaatan sosial. ${ }^{7}$ Sedangkan menurut W.S Winkel, bimbingan berarti "pemberian bantuan kepada sekelompok orang dalam membuat pilihan-pilihan secara bijaksana dalam mengadakan penyesuaian diri terhadap tuntunan-tuntunan hidup". ${ }^{8}$ Bantuan yang dimaksud ialah berupa dorongan dan penguatan psikis bukan dalam ranah materialis.

\footnotetext{
${ }^{7}$ pertama dikemukakan dalam Years Book of Education 1995 dalam Hallen A, Bimbingan dan Konseling dalam Islam (Jakarta: Ciputat Pers. 2002), h. 2

${ }^{8}$ Samsul Munir Amir, Bimbingan dan Konseling Islam (Jakarta: Amzah, 2010), h. 7
} 
Bantuan ini bertujuan untuk memberikan pemahaman dan pelatihan diri dalam menghadapi situasi tertentu dalam masyarakat yang berbeda saat haji. Haji ialah kegiatan berbibadah kepada Allah tetapi dengan beberapa ritual dan tempat yang berbeda serta waktu yang berbeda pula, sehingga menjadi calhaj diuntut untuk mampu menyesuaikan kondisi dan situasi agar tidak terjadi kesalahan dalam beribadah. Sebab serangkaian ibadah wajib haji yang dilakukan oleh jemaah tidak hanya dilakukan sendiri melainkan berbarengan dengan jutaan umat muslim dari seluruh dunia.

Sedangkan "Manasik" secara etimologi berasal dari kata fi'il madi "nasaka, yansuku, naskan" yang artinya ibadah." Al-Qur'an menjelaskan manasik dalam Q.S al An'am 162:

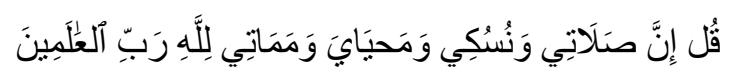

"Katakanlab: sesunggubnya sembahyangku, ibadatku, bidupku dan matiku banyalab untuk. Allah, Tuban semesta alam"

kata نتُسُكِي ibadah, sedangkan haji memiliki arti Kata "haji" secara etimologi atau bahasa berasal dari akar kata :

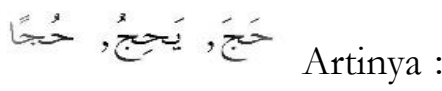
"Menuju tempat tertentu” atau "Mengunjungi ka'bah untuk melaksanakan haji atau umrah. Ulama membedakan istilah yang berkunjung ke Baitullah untuk beribadah dengan berkunjung karena urusan lain seperti untuk berdagang sehingga dikatakan

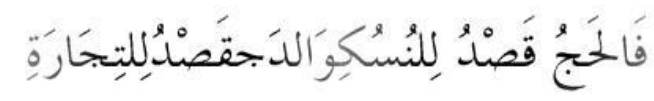

"Kata bajju mengunjungi Baitullab untuk tujuan nusuk (ibadah) dan kata dajju untuk. tujuan berniaga" 10

${ }^{9}$ Munawir, Warson Ahmad, Kamus

Bahasa Indonesia Al-Munawwir, (Yogyakarta: 1984). h, 1414

${ }^{10}$ Depag RI, Panduan Pelestarian Haji Mabrur, (Jakarta : Direktorat Jendral Bimas, 2003), h, 4. 
Pada pemaparan diatas dapat disimpulkan bahwa bimbingan manasik merupakan upaya memberikan arahan atau petunjuk dalam beribadah menuju ke baitullah. Ibadah Haji diwajibkan Allah kepada kaum muslimin yang telah mencukupi syarat-syaratnya. Menunaikan ibadah haji diwajibkan hanya sekali seumur hidup. Selanjutnya yang kedua kali dan seterusnya hukunya sunnah. Barang siapa yang bernadzar haji, wajib melaksanakanya. Adapun beberapa materi dalam manasik haji ialah syarat wajib haji seperti Islam, baligh (dewasa), Aqil (berakal sehat), merdeka (bukan budak), dan Istitha'ah (mampu). Sedangkan rukun Haji adalah Ibram (niat), Wukuf di Arafah, Tawaf Ifadah, Sa’i, cukur, dan tertib. Rukun haji tidak dapat ditinggalkan apabila tidak dipenuhi, maka hajinya batal. ${ }^{11}$ Adapun beberapa wajib haji yaitu;

1) Ihram,

Yakni niat berhaji dari miqat, waktu memulai berihram haji yaitu tanggal 1 Dzulhijjah sampat terbit 10 Dzulhijjah. Miqat ihram jamaah haji Indonesia gelombang I adalah Zulhaifah (Bir Ali), sedangkan bagi jamaah haji gelombang II adalah di atas udara pada garis sejajar dengan Qarnul Manazil atau dapat berihram di King Abdul Aziz Airport (KAAIA), atau dapat di asrama haji Embarkasi Tanah Air. Apabila melewati Miqat yang telah ditentukan dan tidak ihram, maka dia wajib membayar dam yaitu memotong seekor kambing atau mengambil cara lain sebagai ialah dengan kembali lagi ke Miqat Haji terdekat yang dilewati tadi sebelum melakukan salah satu kegiatan ibadah haji atau umrah.

Pakaian Ihram bagi laki-laki memakai dua helai kain yang tidak terjahit (sebagai mana pakaian biasa) satu diselangkang (disandangkan) di bahu dan

\footnotetext{
${ }^{11}$ Syaikh 'Ali bin Hasan bin 'Ali al-Halabi al-Atsari, Panduan Praktis Manasik Haji dan Umrah Menurut Al-Qur'an dan As-Sunnah, (Pustaka Imam ASY-Syafi'I: Tp, Tt), h, $35-88$.
} 
satu disarungkan. Pada melakukan tawaf, kain ihram dikenakan dengan cara idtiba' yaitu dengan membiarkan bahu sebelah kanan terbuka sedangkan bahu sebelahkiri tertutup kain ihram. Disunnahkan memakai kain putih. Bagi wanita, memakai pakaian menutup seluruh tubuh kecuali muka dan kedua tangan dari pergelangan tangan sampai ujung jari.

2) Mabit di muzdalifah

Bagi yang tiba di Muzdalifah sebelum tengah malam harus menunggu sampai tengah malam. Pada saat mabit hendaknya bertalbiyah, berzikir, ber istiqhfar, berdo'a atau membaca Al Qur'an selanjutnya mencari kerikil atau batu sebanyak 7 atau 49 atau 70 butir. Kerikil dapat diambil dari mana saja, tetapi disunnatkan dari Muzdalifah. Jamaah haji yang tidak melaksanakan mabit di Muzdalifah diwajibkan membayar dam dengan urutan sebagai berikut: Menyembelih seekor kambing, atau kalau tidak mampu berpuasa 10 (sepuluh) hari yaitu 3 (tiga) hari semasa haji di tanah suci dan 7 (tujuh) hari dilakukan di tanah air. Apabila tidak mampu melaksanakan wajib puasa 3 (tiga) hari di tanah suci, maka mengganti puasa 10 (sepuluh) hari di tanah air yang 3 (tiga) hari dengan niat qadha. Pelaksanaanya dipisahkan antara yang 3 (tiga) hari dengan yang 7 (tujuh) hari selama 4 (empat) hari. Bagi jamaah haji udzur syar'i seperti sakit, mengurus orang sakit, tersesat jalan dan lain sebagainya tidak wajib membayar dam.

3) Mabit di Mina

Waktu mabit yaitu malam tanggal 11, 12, dan 13 Dzulhijjah. Tempat mabit bagi sebagian besar jamaah haji Indonesia adalah di Haratul Lisan. Haratul Lisan adalah termasuk wilayah hokum mabit di Mina.

4) Melontar jumrah ' ula, wustha dan aqabah

Hukum melontar jumrah adalah wajib, apabila tidak melaksanakanya maka dikenakan dam / fidyah. Tata cara melontar jumrah yaitu Kerikil mengena Marma (masuk lobang), mdengan kerikil satu persatu. Melontar dengan 7 (tujuh) kerikil sekaligus, tetap dihitung satu kali lontaran, mjumrah 
dengan urutan yang benar yaitu mulai dengan jumrah 'ula eustha dan terakhir Aqabah, yang dipakai untuk melontar adalah batu kerikil, selain itu tidak sah seperti sandal, payung atau lainnya. Waktu melontar Pada tanggal 10 Dzulhijjah yang dilontarkan jumrah aqabah saja waktu afdhalnya setelah terbit matahari hari Nahr, waktu ikhtiar (memilih) ba'da Dzuhur sampai terbenam matahari dan waktu Jawaz (diperbolehkan) adalah mulai lewat tengah malam 10 Dzulhijjah sampai dengan terbit fajar tanggal 12 Dzulhijjah. Pada hari Tasyrik (11, 12, dan 13 Dzulhijjah) melontar jumrah 'ula wustha dan Aqabah dengan ketentuan waktu yaitu;

a) Waktu afdhal (ulama) ba'da Zawal.

b) Waktu ikhtiar (memilih) sore sampai terbenam matahari.

c) Waktu Jawaz (diperbolehkan) yaitu selain waktu afdhal dan ikhtiar dimulai dari terbit fajar hari yang bersangkutan. Bagi yang nafar awal melontar tanggal 11dan 12 Dzulhijjah. Sedangkan yang nafar tsani melontar tanggal 11, 12, dan 13 Dzulhijjah.

5) Tawaf wada' bagi yang akan meninggalkan makkah

Waktu pelaksanaannya yaitu setelah ada ketentuan dari petugas untuk meninggalkan tanah suci Makkah. Hukum tawaf wada' adalah wajib bagi jamaah haji yang akan meninggalkan Makkah. Bagi jamaah haji yang tidak mengerjakan tawaf wada' diwajibkan membayar dam (menyembelih kambing). Bagi wanita yang sedang haid/nifas dan sakit tidak diwajibkan tawaf wada'. Penghormatanya ke Baitullah cukup dengan memandangnya dari pintu Masjidil Haram. Orang yang hendak meninggalkan Makkah, belum boleh sebelum melaksanakan tawaf wada' lebih dahulu.

Wajib haji apabila ditinggalkan atau dilanggar maka hajinya tetap sah, tetapi wajib membayar dam (denda). Materi manasik akan disampaikan atas beberapa hal:

1. Metode yang tepat 
2. Memanfaatkan waktu tunggu

3. Mewujudkan jamaah yang mandiri.

\section{B. Pemberdayaan Masyarakat}

Secara bahasa pemeberdayaan (emperworment) berasal dari kata power (kekuasaan atau keberdayaan). ${ }^{12}$ Sedangkan menurut para Ahli ialah;

1. Adams dari Kamus Pekerjaan Sosial: " the user participation in services and to self-help movement generally, in which group take action on their own behalf, either in cooperation with, or independently of, the statutory services." 13 Berdasarkan definisi tersebut, Adams mengartikan pemberdayaan sebagai alat untuk membantu individu, kelompok dan masyarakat agar mereka mampu mengelola lingkungan dan mencapai tujuan mereka, sehingga mampu bekerja dan membantu diri mereka dan orang lain untuk memaksimalkan kualitas hidup.

2. Sutoro Eko menyatakan pemberdayaan sebagai proses mengembangkan, memandirikan, menswadayakan, memprkuat posisi tawar-menawar masyarakat lapisan bawah terhadap kekuatan -kekuatan penekan di segala bidang dan sektor kehidupan.

3. Menurut Permendagri RI Nomor 7 Tahun 2007 (pasal 1 ayat 8), tentang Kader Pemberdayaan Masyarakat dinyatakan bahwa pemberdayaan masyarakat adalah suatu strategi yang digunakan dalam pembanguna

12 Edi Sugarto, Membangun Masyarakat Memberdayakan Rakayat Kajian Strategis Pembangunan Kesejabteraan Sosial Dan Pekerja Sosial, Cet Ke-1, (Bandung: PT Ravika Adimatama 2005),h. 57.

${ }^{13}$ Lihat Robert Adams, Social Work and Empowerment. 3rd ed.( New York: Palgrave Macmillan, 2003) 
masyarakat sebagai upaya untuk mewujudkan kemampuan dan kemandirian dalam kehidupan masyarakat, berbangsa, dan bernegara. ${ }^{14}$ Beberapa pengertian dapat disimpulkan bahwa pemberdyaan merupakan proses atau uapaya untuk membangun masyarakat agar mengelola dan memaksimalkan lingkungan untuk mewujudkan kemandirian hidup bermasyarakat. Sedangkan dalam paradigma Islam, pemberdayaan dipandang sebagai strategi untuk membangun masyarakat yang lebih produktif. Sebagaimana menurut Istiqomah dalam Jurnal Pengembangan Masyarakat Islam menyatakan, pemberdayaan dalam pengembangan masyarakat Islam merupakan sebuah pembelajaran kepada masyarakat dengan bertujuan agar masyarakat secara mandiri melakukan upaya-upaya perbaikan kualitas diri dan mensejahterakan diri di dunia dan keselamatan di akhirat. ${ }^{15} \mathrm{Jim}$ lfe dalam pengalaman Al-Qur'an, mengatakan bahwa pemberdayaan merupakan upaya penyediaan sumber daya, kesempatan, pengetahuan, dan keterampilan bagi masyarakat untuk meningkatkan kapasitas mereka sehingga mereka bisa menemukan masa depan mereka yang lebih baik. ${ }^{16}$ Sedangkan Agus Efendi yang dikutip Nanih Machendrawaty dan Agus Ahmad Safei dalam bukunya Pengembangan Masyarakat Islam, menawarkan tiga konsep yaitu Pertama, pemberdayaan pada matra ruhaniah. Pemberdayaan ini diperlukan karena degradasi moral masyarakat Islam saat ini sangatlah memprihatinkan. ${ }^{17}$ Kedua, pemberdayaan

${ }^{14}$ Kemendagri, Permen No. 072007 tentang Kader Pemberdayaan Masyarakat, (Kementrian Dalam Negeri: 2007)

${ }^{15}$ Matthoriq, dkk, Aktualisasi Nilai Islam Dalam Pemberdayaan Masyarakat Pesisir (Studi Pada Masyarakat Bajulmati, Gajabrejo, Kecamatan Gedangan, Kabupaten Malang), Jurnal Administrasi Publik (Jap), Vol. 2, No. 3, Hlm 427

${ }^{16}$ Jim Ife, Community Development, (Yogyakarta: Pustaka Belajar, 2006), h, 182

$17{ }^{13}$ Dian Iskandar Jaelani,Pemberdayaan Ekonomi Umat Dalam Perspektif Islam (Sebuah Upaya Dan Strategi), Eksyar, Volume 01, Nomor 01, Maret 2014: 018-034, blm 19 
intelektual. Saat ini dapat disaksikan betapa umat Islam yang ada di Indonesia sudah terlalu jauh tertinggal dalam kemajuan dan penguasaan IPTEK, dan Ketiga, pemberdayaan ekonomi.

Tujuan Pemberdayaan masyarakat ialah untuk memampukan dan memandirikan mansyarakat terutama dari kemiskinan dan keterbelakangan, kesenjangan, dan ketidakberdayaan. Namun selain itu pemberdayaan masyarakat juga memiliki tujuan untuk memberikan keterampilan lain kepada masyarakat, dan dalam suatu kegiatan lain bertujuan untuk mengisi waktu luang dengan kegiatan yang bermanfaat. Pemberdayaan selama ini hanya dipandang sebagai suatu kegiatan untuk sekelompok orang yang tidak mampu berdaya (mandiri) atau berdikari (berdiri sendiri). ${ }^{18}$ Namun pada dasarnya pemberdayaan mengalami perkembangan dan pergeseran makna sebagaimana alur globalisasi, bahawa pemberdayaan bukan saja untuk mereka yang belum mampu mandiri tetapi bisa saja untuk mereka yang tidak ada kesibukan bahkan sebagai sarana atau strategi tertentu dalam membangun masyarakat yang kokoh (memperkokoh persaudaraan).

Sebagaimana calhaj di Indonesia bahwa waktu tunggu yang lama menimbulkan kejenuhan dan lesunya jiwa. Hal tersebut dapat dianalogikan dengan sekelompok narapidana yang memiliki latar belakang dan kondisi perekonomian yang berbeda. Para narapidana tidak hanya berasal dari masyarakat tidak mampu, melainkan juga dari kalangan mampu. Namun untuk mengisi kegiatannya selama dalam Rumah Tahanan, pemerintah memberikan beberapa pelatihan dan mengasah ketrampilan para NAPI (Nara Pidana), selain untuk memberikan bekal keterampilan agar kelak setelah keluar dari Rumah Tahanan mereka mampu Berdikari juga untuk memanfaatkan waktunya dan menghilangkan kejenuhan. Jelas dalam analog

18 H. Moh Ali Azis, Dakwah Pemberdayaan Masyarakat: Paradigma Aksi Metodologi, (Yogyakarta; LKiS, 2005), h, 128. 
tersebut bahwa waktu luang yang tidak dimanfaatkan dengan baik akan membawa dampak negatif pada diri seseorang. Karena dalam waktu luang seseorang akan berusaha untuk berpikir keras tentang hal-hal yang rumit dan angannya melambung dalam situasi-situasi yang sulit. ${ }^{19}$ Yahya menjelaskan untuk memanfaatkan waktu luang ialah dengan menghindari kenyataan yang dapat menimbulkan stres, namun hal tersebut bisa dikatakan mustahil yang mungkin bisa dilakukan yaitu dengan mengelola stres agar tidak merugikan dan berbanding terbalik ialah justru akan dapat memacu semangat. ${ }^{20}$

Adapun beberapa cara mengelola kekosongan waktu ialah untuk recovery kesehatan jasmani, kesehatan rohani, sosialisasi diri di masyarakat, kestabilan ekonomi, dan kesuksesan manajemen.

1. Memanfaatkan Waktu luang untuk recovery kesehatan jasmani

Waktu luang dapat digunakan oleh seseorang dengan berolahraga dan menikmati melatih urat syaraf bebas dari ketegangan. Pemanfaatan waktu luang untuk meningkatkan kesehatan diantaranya, membiasakan berolahraga, makan makanan ringan yang akan memberikan semangat, mengendurkan urat-urat syaraf dengan bersantai, dan menjauhi tempat keramaian yang dapat menimbulkan kebisingan di sekitar tempat beraktifitas.

2. Waktu luang untuk kesehatan rohani

Seseorang bisa berinteraksi dengan dua obyek yaitu obyek ekstern dan obyek intern. Individu yang melakukan sesuatu maka akan berkonsentrasi pada realita luar yang memberi efek pada tindakannya tersebut. Jika hal itu

19 Khalil, A. Khavari, Ph. D. The Art Happiness, Jakarta: Serambi Ilmu Semesta, 2000), h 378

${ }^{20}$ Yahya, L. R. S, Kumpulan Artikel Psikologi 2, (Jakarta: Intisari Mediatama, 2005), h, 16 
terjadi maka seseorang akan mengalami gangguan jiwa. Aktivitas kejiwaan agar individu paham dan membiasakannya sehingga memiliki kesehatan yang baik, yaitu: saling bertemu dengan seseorang yang memiliki orientasi sama selain untuk memupuk silturrahmi juga untuk memberikan semangat satu dengn lainnya.

3. Waktu luang untuk sosialisasi diri di masyarakat

Dalam interaksi sosial baik dalam individu maupun kelompok berpotensi untuk memberikan pengaruh positif pada lingkungan. Pentingnya waktu luang yang sesuai dan cukup untuk merealisasikan keharmonisan sosial dalam hubungan sosial, seperti:

a) Melakukan evaluasi diri dengan ingkungannya.

b) Menilai strata sosial yang dimiliki seseorang dalam satu komunitas.

c) Memprediksi masa depan.

d) Merencanakan masa depan.

e) Menyiapkan media aplikasi yang sesuai

4. Waktu luang untuk kestabilan ekonomi

Menggunakan waktu luang untuk mengisi kegiatan bermanfaat terutama yang dapat mendorong dan membangun perekonomian.

5. Waktu luang untuk kesuksesan manajemen

Waktu luang dipergunakan untuk berkomunikasi dengan orang lain, bekerja sama dengan mereka, bersama-sama memikul tanggung jawab dan bangkit bersama mereka akan dapat meminimalisir ketegangan. ${ }^{21}$

Beberapa kegiatan yang dilakukan dalam mengisi waktu tunggu calon jamaah haji bertujuan untuk:

1. Memperbaiki kualitas diri

2. Membangkitkan semangat

${ }^{21}$ Yusuf Michael As'ad, Sukses Bersama Waktu, (Yogyakarta: Cendekian Sentra Muslim, 2003), h, 19-43.

Abdul Choliq, Esensi Program... 
3. dan mendorong calon jamaah haji agar lebih optimis.

Dikhawatirkan jika Calhaj yang masih menunggu waktu keberangkatan tidak dimanfaatkan waktunya maka kejenuhan dan menurunnya mental akan berdampak pada kesehatan. Selain faktor usia calhaj waktu tunggu yang begitu lama akan berdampak pada psikologi seseorang, sehingga perlunya pemberdayaan calhaj selain untuk mempererat hubungan antar calhaj juga untuk memberikan pemahaman yang berkelanjutan agar tidak mudah lupa. Adapun yang akan memberikan bimbingan berbasis pembedayaan tersebut ialah lembaga-lembaga manasik haji dengan beberapa kegiatan yang mampu mendorong calhaj lebih mandiri dan berkompeten. Beberapa konsep pemberdayaan menurut Wrihatnolo \& Nugroho mencakup:

1. Community development (pembangunan masyarakat)

2. Community-based development (pembangunan yang bertumpu pada masyarakat),

3. Community-driven development yang diterjemahkan sebagai pembangunan yang diarahkan masyarakat atau diistilahkan pembangunan yang digerakkan masyarakat. ${ }^{22}$

\section{ANALISIS PROGRAM BIMBEL MANASIK DALAM PEMBERDAYAAN MASYARAKAT}

Secara umum pemberdayaan dilakukan pada lingkungan yang di dominasi oleh orang-orang yang belum memiliki keterampilan atau belum mandiri. Namun pada penelitian ini pemberdayaan ditujukan bagi calon jamaah haji dengan waktu tunggu lama dan atau yang membutuhkan

\footnotetext{
${ }^{22}$ Randy R.Wrihatnolo \& Riant Nugroho D. Manajemen Pemberdayaan: Sebuab Pengantar dan Panduan untuk Pemberdayaan Masyarakat, (Jakarta: PT Elex Media Komputindo, 2007)
} 
pemahaman tentang ibadah haji secara menyeluruh sehingga dapat mewujudkan jamaah haji mandiri. Mewujudkan haji mandiri bagi Kementrian Agama merupakan targeet utama, karena hal tersebut adalah kunci suksesnya haji Indoensia. Kementrian Agama berusaha untuk membentuk haji mandiri, hal ini terlihat pada saat dilakukan bimbingan (manasik) calon jamaah haji. Kementrian agama berusaha menciptakan para petugas profesional yang berdedikasi untuk membantu menyelesaikan permasalahan para jamaah di Tanah Suci. Namun usaha tersebut belum menuai hasil yang memuaskan, sebab dari tahun ke tahun permasalahn jamaah berfariasi. Meski berfaiasi tetapi ada beberapa yang masih menjadi permasalahan lama, yaitu minimnya pengetahuan jamaah tentang beberapa cara ibadah dan ketentuan-ketentuannya. Sebagaimana yang telah diuraikan dalam latar belakang, bahwa penambahan kuota tidak lantas menjadi solusi haji di Indonesia, justru memberikan pekerjaan rumah (PR) besar bagi Kementrian Agama selaku penyelenggara.

Kementrian Agama memiliki tugas berat dalam menyelesaikan haji, sebab jika penambahan kuota tidak diiringi dengan pelayanan yang baik maka akan menimbulkan masalah baru yang dapat memberikan dampak negatif pada jamaah haji. Sebagaimana yang di lansir dalam surat kabar bahwa jumlah jamaah dengan petugas timpang, yaitu jamaah yang berangkat tahun 2017 ialah 221.000 orang sedangkan petugas pembimbing haji hingga 2018 yang tersertifikasi baru 3.001 orang. Artinya dari setiap satu pembimbing mendapatkan tanggung jawab 74 orang jamaah, melihat kenyataan tersebut, sangat wajar jika calon jemaah haji merasa kuatir untuk tidak mendapatkan bimbingan dengan semestinya. Apalagi prosentasi calhaj (calon jemaah haji) merupakan dari kalangan lansia, tentu kekhawatiran berlebih akan muncul. Maka manasik haji hendaknya dilakukan secara intensif dan orientatif, sebab pemahaman dan pengetahuan hendaknya 
dibangun bukan secara instant tetapi berkelanjutan sampai calhaj benarbenar mampu secara psikis dan keilmuan.

Kondisi dilapangan menyatakan bahwa rasio antara petugas dengan jumlah jamaah belum memadai, serta apakah telah mampu memberikan pemahaman kepada jamaah dengan baik, mengingat perbedaan tingkat pendidikan, pemahaman ilmu agama, usia, budaya, karakter manusia ataupun kelas sosial sangat beragam. Sisi lain yang harus dipertimbangkan adalah para calon jamaah dalam satu regu, pada umumnya baru saling kenal, akibatnya kurang memahami watak satu orang dengan orang lainnya. Sehingga kebersamaan ataupun rasa persaudaraan belum terbentuk dengan baik. Jika ada jamaah memiliki masalah, baik dalam hal kesehatan, permasalahan ibadah ataupun lingkungan baru kadang belum bisa disampaikan secara terbuka di dalam regunya. Kondisi ini akan berakibat munculnya stres-stres di dalam kehidupanbarunya yang jauh dari keluarganya. Kementrian Agama dalam menghadapi permasalahn tersebut, hendaknya di bantu oleh beberapa lembaga bimbingan haji yang memiliki program bimbel manasik pada pemberdayaan masyarakat. Beberapa program manasik yang memiliki esensi pada pemberdayaan masyarakat ialah:

1. Menggunakan Metode yang Tepat

Penyampaian materi manasik kepada audien yang di dominasi oleh lansia hendaknya menggunakan metode yang tepat. Penyampaian tersebut dapat menggunakan beberupa metode:

a) Affirmation and repetition, yaitu memberikan pengulangan dan penekanan pada materi-materi wajib. Repetition (pengulangan) dapat dipraktikan tidak hanya pada satu waktu tetapi di beberapa waktu hingga jamaah benar-benar mengafal dan memahami materi. Pemahaman materi dapat dilihat melalui evaluasi setiap akhir pertemuan. Repetition selain sebagai metode menyampaikan materi dengan cara ringan juga memberikan 
perasaan senang kepada jamaah. Sehingga jamaah tidak merasa bosan dan materi dapat tertanam dengan mudah dalam pikiran jamaah. ${ }^{23}$

b) PAIKEM (Pembelajaran, Aktif, Inovatif, Kreatif, Efektif, dan Menyenangkan). Metode PAIKEM ini bisanya digunakan pembimbing sebagai alternatif untuk mmengkondisikan audien agar lebih aktif baik dalam individu maupun kelompok. ${ }^{24}$ PAIKEM di rasa sesuai untuk diterapkan dalam kelompok belajar yang di dominasi oleh para orang tua (khususnya calhaj). Membimbing calhaj yang di dominasi oleh lansia dengan remaja tentu berbeda. Perbedaan tersebut tidak hanya dikarenakan oleh rentan umur tetapi juga dikarenakan kondisi psikologis calhaj. Secara psikologis lansia mudah bosan dan lamban dalam memahami materi, maka untuk memberikan kemudahan pembimbing dapat menggunakan metode PAIKEM. Pembimbing dapat memberikan sentuhan lain pada setiap materinya, misalnya versi shalawat yang di isi dengan materi Ihram, Sa'i, Thawaf dan lainnya.

SYAIR UMRAH
gelombang I
YA RASULALLAH SALAMUN ALAIK
Yaa rasuulallah salaamun alaik
Yaa rofii a'sy syaa niwadda roji
Athfata yajii rotal 'alami
Ya uhailaljuu diwal karomi $2 x$

23 Tanya Ovenden-Hope, Sonia Blandford, Understanding Applied Learning; Developing Effevtive Practice to Support Alla Learners, (New York: Routladge, 2018).

${ }^{24}$ Jejen Musfah, Menejemen Pendidikan Teori, Kebijakan, dan praktik, (Jakarta: Kencana, 2015), h, 122

Abdul Choliq, Esensi Program... 
Haji dan Umroh di tanah suci

Akan menghadap ILlahi robbi

Harus niat suci dan bersihkan hati

Ikhlas, sabar, jangan selalu emosi $2 x$

Mulai dari rumah, hanya cari barokah

Niat ibadah jangan sampai serakah

Sampai bandara.menuju hotel madinah

Sholat arbain, berdo'a dan ziaroh $2 \mathrm{x}$

Rajin berdo'a di Taman Roudhoh

ucapkan salam pada Rosul, dan sahabatnya

Smoga memproleh Ridho dan Syafaatnya

Hidup Istiqomah akhir Khusnul khotimah 2x

Setelah ziarah dan menata hati

Menuju Mekah sholat sunah di Ber ali

Niat Umroh akan menuju di Baitullah

Jangan lupa dzikir,dan baca talbiyah $2 \mathrm{x}$

\section{BACA TALBIYAH BERSAMA-SAMA}

Umroh itu ihni thosakur

Ihrom niat thowaf, sai dan cukur

Umroh itu ihni thosakur

Ihrom niat thowaf, sai dan cukur

Umroh itu ihni thosakur

Ihrom niat thowaf sai dan cukur

Selama di mekkah perbanyak ibadah

Baca Al-quran jangan lupa thowaf sunah 
Rajin shodaqoh selalu cari ridho allah

Semoga kita sehat dan barokah $2 \mathrm{x}$

\section{BACA TALBIYAH BERSAMA-SAMA}

Haji itu ihniwumamuz min lontoi sakur tahalul Haji itu ihniwumamuz min lontoi sakur tahalul Haji itu ihniwumamuz min lontoi sakur tahalul

\section{$\underline{\text { Kembali ke Yarosulullah }}$}

$8 \mathrm{dZulhijah} \mathrm{menuju} \mathrm{Arofah}$

Jangan lupa bersih diri sucikan hati

Niat haji bawa bekal taqwa dan pasrah

Banyak istighfar janji tinggalkan mungkar $2 \mathrm{x}$

9 dzulhijah wukuf di Arofah

Dengarkan khutbah untuk muhasabah

Sholat jama takdim dhuhur asar berjamaah

Smoga mendapat barokah dan maghfiroh x2

10 Dzulhijah ke Muzdalifah

Ambil 7 kerikil untuk melontar aqobah

Mu'dhomul lail kita menuju mina

Mabit disana tinggalkan dosa.X2

Mlontar ketiga jamrah,ula wustho aqobah

Tanggal sebelas,duabelas dzulhijjah

Bila nafar awal,segera kita ke Mekkah

Melaksanakan rukun haji,thowaf ifadloh x2

Setelah thowaf wada" menuju ke Jeddah

Selalu berdoa agar selamat sampai rumah

Smoga jadi haji mabrur- mabruroh

Ahli ibadah,manfaat barokah x2

Rajin beramal dan sholat jamaah 
Suka berkorban untuk amal ibadah

Menjaga diri dan suka silaturrahmi

Ke sesama haji,santri- ulama-kiyai x2

Mari berdoa dan slalu bersyukur

Agar haji kita menjadi mabrur

Hidup manfaat untuk seluruh ummat

Semoga selamat,dunia akherat x2

HAJI MABRUR

Haji mabrur itu rahasia Allah

Tanda-tanda menurut Rosulullah

Ajak kebaikan dan tebarkan salam

Rajin ibadah, suka perdamaian $2 \mathrm{x}$

Slalu peduli kepada sesama

Anak yatim, fakir miskin utamanya

Slalu membantu dan tidak menghardiknya

Bersikap baik, ramah ucapannya 2x Aamiin.

\section{Puitisasi}

Ya Allah,

Aku bersujud pada $\mathrm{Mu}$

Bertasbih pada $\mathrm{Mu}$

Sepanjang waktu

Ya allah, engkau Maha Suci

Maha menepati janji

Engkau yang kekal

Tak pernah hilang

Ditangan Mu lah

Letak kebajikan

Kepada Mu lah 
Kami dikembalikan

\section{Bahasa Jawa}

Ya Allah,

Kulo sujud dateng panjenengan

Kulo tasbih dateng panjenengan

Ndalu lan rinten

Ya Allah,

Kang Moho suci

Moho netepi janji

Moho kekal

Ora bakal ilang

Panggenan kesaenan

Panggenan wangsulan

\section{Memanfaatkan Waktu Tunggu}

Waktu tunggu yang di alami calon jamaah haji yang di dominasi oleh lansia ini hendaknya dipergunakan untuk kegiatan yang konstruktip sehingga mencegah hal-hal yang bersifat distruktip. Sebab selain untuk memberikan kegiatan bermanfaat bagi calhaj dalam memanfaatkan waktu tunggu, kegiatan-kegiatan juga memberikan ruang dan waktu bagi calhaj untuk lebih kenal dengan calhaj yang lain, sehingga rasa persaudaraan dan kekeluargaan tumbuh dengan baik. Adapun kegiatan-kegiatan yang dapat dilakukan dalam pembekalan seperti:

a. Bersama-sama dalam pembuatan tanda-tanda perbekalan haji, seperti tanda pita, masker, atau slendang leher.

b. Melatih penanaman tanaman apotik hidup

c. Pembuatan beberapa barang untuk memepersiapkan keberangkatan haji, misalnya tas-tas kecil untuk penyimpanan barang dan lainnya. 
3. Mewujudkan Jamaah yang Mandiri.

Jama'ah mandiri merupakan cita-cita penyelengggra haji Indonesia ialah Kemeterian Agama (khususnya) dan masyarakat (pada umumnya), sebab dengan demikian permasalahan yang selama ini menyertai haji Indonesia dapat ditekan. Mengingat sebagian besar calhaj Indonesia didominasi oleh lansia. Kemandirian calhaj yang diharapkan tidak hanya pada keilmuan tentunya juga pada ranah psikologis. Maka untuk memenuhi hal tersebut hendaknya lembanga bimbingan manasik haji memanfaatkan waktu tunggu yang lama ini untuk memantapkan materi dan mental calhaj. Pemantapan materi tidak hanya dapat dilakukan dengan menambah waktu saat manasik tetapi juga ruang temu. Sebab dengan seringnya calon jamaah bertemu dengan jamaah lain, maka akan memberikan dampak positif bagi para calhaj, seperti:

a. Menumbuhkan semangat bagi jamaah untuk lebih meningkatkan ibadah kepada Allah

b. Memberikan semangat dalam menjaga kesehatan baik sebelum keberangkatan, saat berhaji, dan setelah haji.

c. Merekatkan talisilaturrabim antar calhaj agar terwujudnya ukhuwah Islamiyyah yang kokoh.

\section{KESIMPULAN}

Haji sebagai ibadah sakral dengan segala praktiknya menuntut setiap calon jamaah untuk memenuhi syarat utamanya ialah mampu. Mampu tidak hanya dalam hal materi tetapi juga mampu dalam ruhani dan pengetahuan. Maka untuk memenuhi pengetahuan dan pemahaman ibadah haji diperlukan manasik haji secara intensif. Sebab melihat realitas yang ada bahwa Tahun 2017 keberangkatan haji masih menyisakan permasalahan yang tidak jauh berbeda dengan tahun-tahun sebelumnya. Misalnya jumlah pembimbing dan jamaah haji masih timpang dan waktu tunggu keberangkatan calhaj yang begitu lama sehingga dapat memberikan dampak 
negatif bagi calhaj. Permasalahan tersebut perlunya melihat kondisi yang ada bahwa calon jamaah di dominasi oleh lansia sehingga jika terjadi lupa atau belum paham tentang pratik atau tata cara haji, dikhawatirkan akan membatalkan atau haji tidak syah. Maka untuk mengantisipasi hal tersebut di perlukan jumlah pembimbing yang seimbang, selain itu yang menjadi penting ialah mewujudkan calon jamaah yang mandiri. Jamaah mandiri dapat direalisasikan dengan membentuk kelompok manasik yang konstruktif ialah selain memberikan materi dengan cara menyenangkan dan memahamkan juga memberikan kegiatan-kegiatan yang dapat mendorong pemberdayaan calhaj. Kegiatan ini selain untuk mengisi waktu tunggu yang lama juga untuk memberikan media bagi calhaj agar lebih banyak bertemu dengan calhaj yang lain sehingga tumbuh optimisme dalam diri calhaj dan mengurangi tekanan/stress selama waktu tunggu tersebut. Kegiatan memanfaatkan waktu tunggu dapat berupa pelatihan pembuatan perbekalan seperti pembuatan pita sebagai tanda jamaah haji, pelatihan menanam apotik hidup, dan pembuatan beberapa barang untuk memepersiapkan keberangkatan haji, misalnya tas-tas kecil dan barang lainnya.

Demikian pembahasan ini kami buat, semoga dapat memberikan manfaat bagi pembaca. Jika ada kesalahan dalam penulisan atau redaksi, murni adalah kesalahan penulis. Maka penulis harap ada kritik yang membangun dari pembaca, guna untuk mebenahi tulisan-tulisan berikutnya, Terimakasih.

\section{DAFTAR PUSTAKA}

Depag RI, Panduan Pelestarian Haji Mabrur, (Jakarta : Direktorat Jendral Bimas, 2003). 
Dian Iskandar Jaelani, Pemberdayaan Ekonomi Umat Dalam Perspektif Islam (Sebuah Upaya Dan Strategi), Eksyar, Volume 01, Nomor 01, Maret 2014: 018-034.

Edi Sugarto, Membangun Masyarakat Memberdayakan Rakayat Kajian Strategis Pembangunan Kesejabteraan Sosial Dan Pekerja Sosial, Cet Ke-1, (Bandung: PT Ravika Adimatama 2005).

H. Moh Ali Azis, Dakwah Pemberdayaan Masyarakat: Paradigma Aksi Metodologi, (Yogyakarta; LKiS, 2005).

Jim Ife, Community Development, (Yogyakarta: Pustaka Belajar, 2006).

Kemendagri, Permen No. 072007 tentang Kader Pemberdayaan Masyarakat, (Kementrian Dalam Negeri: 2007)

Khalil, A. Khavari, Ph. D. The Art Happiness, Jakarta: Serambi Ilmu Semesta, 2000).

Matthoriq, dkk, Aktualisasi Nilai Islam Dalam Pemberdayaan Masyarakat Pesisir (Studi Pada Masyarakat Bajulmati, Gajahrejo, Kecamatan Gedangan, Kabupaten Malang), Jurnal Administrasi Publik (Jap), Vol. 2, No. 3.

Munawir, Warson Ahmad, Kamus Bahasa Indonesia Al-Munawwir ,(Yogyakarta: 1984)

Murad Wilfred Hoffman, Jalan Menuju Mekkah, Terj: Abdul Hayyie al Kattani dkk, (Jakarta: Gema Isnasi Press, 2000),

Musfah, J. Menejemen Pendidikan Teori, Kebijakan, dan praktik, (Jakarta: Kencana, 2015)

Pikiran Rakyat, Jemaah Haji Harus Pabami Budaya Arab, diakses dalam http://www.pikiran-rakyat.com/info-haji/2013/09/24/252076/jemaah-hajiharus-pahami-budaya-arab, pada Jum'at 10 Mei 2018, pukul 00.32 WIB.

Randy R.Wrihatnolo \& Riant Nugroho D. Manajemen Pemberdayaan: Sebuah Pengantar dan Panduan untuk Pemberdayaan Masyarakat, (Jakarta: PT Elex Media Komputindo, 2007) 
Reni Shiren Aulia, Jumlah Jemaah Haji Indonesia Yang Masuk Daftar Tunggu! http://www.alshaumroh.com/2017/02/jumlah-jemaah-hajiindonesia-yang-masuk-daftar-tunggu.html, diakses pada Jum'at 10 Mei 2018 pukul 00. 54 WIB.

Republika.co.id, 'Bimbingan Manasik Haji Kurang Optimal, di posting pada 30 desember 2015 pukul 16.54 WIB.

Robert Adams, Social Work and Empowerment. 3rd ed.( New York: Palgrave Macmillan, 2003)

Samsul Munir Amir, Bimbingan dan Konseling Islam Jakarta: Amzah, 2010).

Syaikh 'Ali bin Hasan bin 'Ali al-Halabi al-Atsari, Panduan Praktis Manasik Haji dan Umrah Menurut Al-Qur'an dan As-Sunnah, (Pustaka Imam ASY-Syafi'I: Tp, Tt).

Tanya Ovenden-Hope, Sonia Blandford, Understanding Applied Learning; Developing Effevtive Practice to Support Alla Learners, (New York: Routladge, 2018).

Widyarini, Penyelenggara Ibadah Haji bagi Lansia, Jurnal: Az Zarqa', Vol.8, No.2 Desember 2016.

Yahya, L. R. S, Kumpulan Artikel Psikologi 2, (Jakarta: Intisari Mediatama, 2005).

Years Book of Education 1995 dalam Hallen A, Bimbingan dan Konseling dalam Islam (Jakarta: Ciputat Pers. 2002).

Yusuf Michael As'ad, Sukses Bersama Waktu, (Yogyakarta: Cendekian Sentra Muslim, 2003). 